\title{
THE FAMILY OF INDRIKIS BLANKENBURGS (1887-1944) AND ARCHITECTURAL PROJECTS IN THE TURN OF THE CENTURY
}

MĀRIS ZVAIGZNE**

Riga State German Grammar School ALĪDA ZIGMUNDE, ILZE GUDRO

Riga Technical University

Summary. The graduate of the Department of Architecture (1913) of the Riga Polytechnic Institute (RPI), architect Indrikis Blankenburgs (1887-1944) is one of the best-known architects of school buildings in Latvia during the interwar years. Most of his more than 30 projected schools and other buildings are still used for the original purpose of the architect. Using the documents of the Latvian State Historical Archives and library collections, the article follows the Blankenburgs family and outlines the contribution of I. Blankenburgs to school architecture and provides the list of schools designed by the architect.

Keywords: Indrikis Blankenburgs, the Blankenburgs family, school building projects.

\section{Introduction}

On 7 April 2017, a scholarly-practical conference «School Architect Indrikis Blankenburg - 130» was held at the Riga State German Grammar School. It was marking the anniversary of the graduate of Riga Polytechnic Institute and reviewing his performance and life activity. By studying less well-known pages of his life, the authors of the paper referred about the architect Indrikis Blankenburgs at the conference. The research was carried out by analysing the documents of the Latvian State Historical Archive, the Riga State German Grammar School Museum and the National Library of Latvia, including articles in the periodicals.

* Corresponding author.

E-mail: maris_zvaigzne@inbox.lv 
A research about architect Indrikis Blancenburgs' family was conducted for the first time, gaining information about both parents and sisters and brothers. The story of Blankenburgs family is much like the fate of other Latvian families - deportation to Siberia during the Soviet time, emigration at the end of the Second World War, the beginning of a new life in exile. The architect's projects of buildings are kept in the Latvian State Historical Archive, photos can be viewed at schools, libraries and museums. The buildings projected by I. Blankenburgs are still serving to Latvia and its people, are available in all cultural and historical regions of Latvia - Kurzeme, Latgale, Vidzeme and Zemgale.

\section{Family of Blankenburgs}

The roots of Blankenburgs' family can be found in Liepāja and Vircava. It is also believed that the relatives of Indrikis Blankenburgs' father Jānis Blankenburgs, born on 8 November 1852 in Vircava parish, lived in Liepāja. Jānis Blankenburgs settled in Riga in the 1870s, where he lived with four children - three sons and a daughter, and his wife Katrina Blankenburgs, born Mikelsons. Jānis Blankenburgs was a craftsman, he worked as an ironworker in the Baltic Wagon Factory and later became a master at the wagon factory «Fēnikss» [1]. He and his family lived in different places in Riga, while collecting money and acquiring property at 5 Plavas Street [2]. Katrina died in the beginning of the 20th century, Jānis - on 25 April 1934.

Figure 1. Architect Indrikis Blankenburgs' father Jānis Blankenburgs (around 1927) [1].

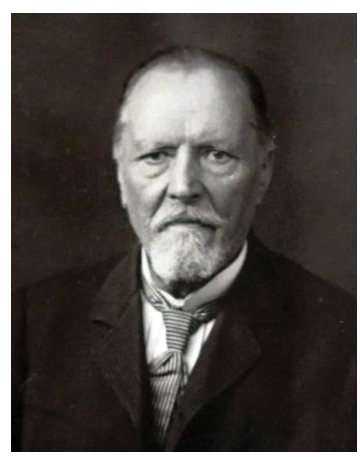

Ferdinands Blankenburgs, the oldest son of Jānis Blankenburgs, was born on 13 April 1877 in Riga, and, like his father, chose a profession of ironworker. The first spouse soon passed away, and F. Blankenburgs married Auguste Mekeniks in August 1933 [3]. Alas, the marriage lasted one year, and he again became a widower. In June 1941, F. Blankenburgs was deported to Siberia, and on 24 December, he died in Molotov Oblast, 
Usollag [4]. Arnolds Blankenburgs, the son of Ferdinands Blankenburgs, was born in 1906, worked at the bank, and in 1939, together with his wife Irmgarde and his daughter Urzula travelled to Germany because of his German nationality [5]. Ferdinands Blankenburgs' daughter Erna (1902-?) was married to Alfreeds Otto (1902-1940) and, at the end of the Second World War, she and her daughter Helēna and son Perijs became refugees. She worked in assemblage Daugavas Vanagi in England.

Arturs Blakenburgs, the second son of Jānis Blankenburgs, was born on 17 November 1881. He worked as a railway technician and did not create a family. He also suffered from the repression of the Soviet power - in 1941, Arturs was arrested, imprisoned at the Riga Central Prison and killed in late June [6]. The reason for the repression against the Blakenburgs family was apparently their national spirit and wealth they owned a large house at Plavas Street, near St. Paul's Lutheran Church in Riga where Jānis Blankenburgs' children were baptized and consecrated.

Indrikis Blakenburgs was the third and the youngest son, he was given two names - Indrikis Teodors, though usually the second name was not used in documents. He was born on 7 April 1887', and started attending school at the age of seven. Due to the change of the parents' home, Indrikis studied at several private schools in Riga, but in 1898, he entered the Riga City Real School, the seventh grade of which he graduated in 1905. At that time, Indrikis' elder brothers were already of age and provided for themselves. The parents were Latvians, but in Riga in the second half of the 19th century «the German spirit and German capital dominated», therefore father Jānis Blankenburgs sided with the Germans, thus ensuring existence. Indrikis" "father, who financially heavily depended on them, raised his children according to German ideals, although in his inner conviction he had not lost any sense of his nationality [7].» Indrikis Blankenburgs' native language was Latvian and had good knowledge of German and Russian. Russian was the language of studies at the Real School and later at the Riga Polytechnic Institute.

I. Blankenburgs joined the Riga Polytechnic Institute in 1905. He began to study at the Department of Engineering, but the studies were soon interrupted because of the events of the Revolution of 1905, which led to the closure of the university. In spring 1906, as a free listener, he attended lectures at the Department of Engineering of Danzig Technical High School, but in the autumn continued his studies at the Department of Architecture of RPI. He received the Diploma of Engineer Architect in 1913 [8]. Already during his studies he began working as a trainee in the offices of Vanags, Laube and Nukša. After studies, he worked as a tax collector for the insurance company «Rossija». At the beginning of 1915,

1 The dates in publication are listed according to the Gregorian calendar or new style. 
I. Blankenburgs travelled to Tula in Russia and worked as an engineer of repairing war buildings and structures.

Figure 2. Indrikis Blankenburgs - Student

Corporation «Talavija» furnace at the beginning of the 20th century [9].

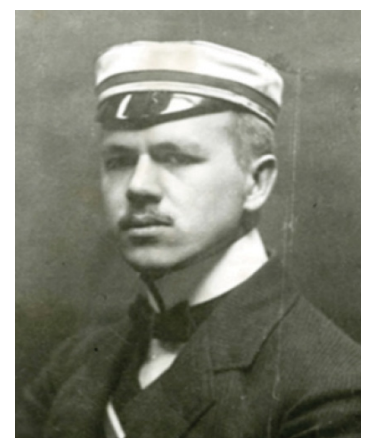

Indrikis Blankenburgs returned to Latvia in 1920. From July 1922 until August 1924, he worked as an architect at the Central Union of Latvian Agriculture. On 8 July 8 1924, Indrikis Blankenburgs started to work at the Technical Office (later - Construction Bureau) at the School Department of the Ministry of Education with a salary of 230 lats per month [10] and worked there until 22 May 1938, when he discontinued his employment on his own wish [11]. The responsibilities at the Bureau included managing the design of school buildings and supervising their construction work throughout Latvia. After 1938, apparently, I. Blankenburgs had a private practice.

Being a student, in 1907, I. Blankenburgs joined the Latvian Student Corporation «Talavija» [12]. He developed friendly relationships with Kärlis Kurle-Kurlis (1888-1928), a student of the Department of Commerce of RPI, who did not finish his studies and then seriously turned to painting. After the early death of the artist, architect I. Blankenburgs built a monument dedicated to his friend in the Meža (Forest) Cemetery in Riga. Blankenburgs had friendly relations also with another member of corporation «Talavija», graduate of RPI (1916), architect Augusts Raisters (1888-1967).

Augusts Raisters characterized his friend and colleague Indrikis Blankenburgs as a composed, deeply sensitive, sincere and honest man. The two last met in the middle of September 1944, at Blankenburgs' house at 5 Plavas Street, in Riga. They both were planning to leave and were hoping to meet again outside Latvia. Augusts Raisters went to Germany, then to the United States. He later remembered that Blankenburgs had packed his travel bags and said that «he did not want and could not stay in Riga, because there was a communist-minded person, one of the former schools janitors, who would compromise him to the communists 
[13].» He wanted to leave Riga in a week's time. Why he did not leave Riga as planned is unknown.

Architect Indrikis Blankenburg passed away in his home on 15 October $1944^{2}$, and was probably buried in the Meža (Forest) Cemetery in Riga, next to artist Kärlis Kurle-Kurlis. Blankenburgs had not set up his family. He had close and good relations with both his brothers and his sister, but at the end of his life they were no longer with him.

Indrikis' sister Emeline Blankenburgs was the youngest child of Jānis Blankenburgs. She was born on 7 September 1897 and was ten years younger than Indrikis, but with her older brother Ferdinands, the difference was even greater - 20 years [14]. Emeline worked as an office employee, later on was an official and married an employee of the Ministry of the Interior Rüdolfs Vanušks (1897-1978), who had studied forestry at the University of Latvia. At the end of the Second World War, Emeline and Rüdolfs went into exhile. She did not know that her brother, having experienced the arrival of the Soviet Army in Riga, committed suicide, therefore in October 1945 in Wuerttemberg, she published a notice in the Latvian newspaper «Dzimtene» («Homeland») that she was looking for her brother Indrikis [15]. After World War II Emelīne Vanušks lived in Esslingen, Germany, along with other Latvian refugees. After a few years, she went to Minneapolis, the United States, where she lived until 3 May 1990 [16]. The Vanušks family did not have descendants, but they had friendly relations with relatives, including brother Ferdinand's grandson Perijs Otto who lived in Australia.

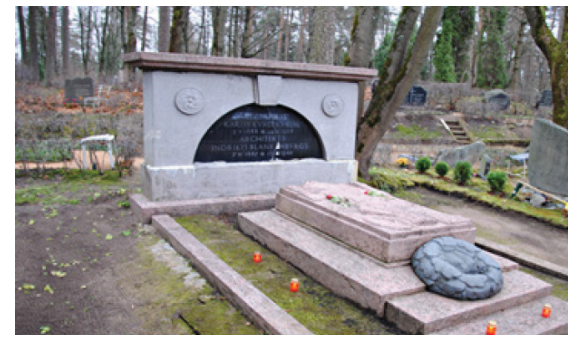

Figure 3. The tombs and monuments to I. Blankenburgs and K. Kurle-Kurlis after restoration at Second Meža (Forest) Cemetery in Autumn 2014 in Riga [17].

Relatives and acquaintances living in emigration found out about Indrikis Blankenburgs' death only in 1965, when his contemporary and member of «Talavija» corporation, Latvian architect Augusts Raisters, published a memorial article dedicated to his colleague in the journal «Architekts» («Architect») [18]. True, information about the death of I. Blankenburgs and other significant Latvian architects, without reference to a particular date, could be found in the December issue of 1950

2 It is hard to clarify the real date, after Riga State German Grammar School data. 
of the same journal [19]. It should be noted, that at the time when the active research on the history of the Riga State German Grammar School began, the director of the school Zane Jakovica and the social pedagogue Inta Miezite initiated an idea of regular visits and cleaning of the tomb of the significant Latvian architect. From 2010, twice a year, in November and May, one school class goes to the Second Meža (Forest) Cemetery and cleans the tomb of I. Blankenburgs. Finally, in 2013, the restoration work of I. Blankenburgs' tomb and monument was successfully completed [20].

\section{Indrikis Blankenburgs' work in architecture}

The most famous representative of the Blankenburgs' family, architect Indrikis Blankenburgs, designed more than 40 school buildings in the 1920s and 1930s. He is one of the most well-known architects of independent Latvian educational institutions. At the beginning of 2017, the Society of School Museums began to compile a list of schools designed by the architect that comprised 29 schools [21]. Over the years, researchers have succeeded and completed the list. In May 2018, 43 educational institutions were registered, whose buildings or their annexes were designed or reconstructed by I. Blankenburgs. Various Latvian publications have reflected almost all of I. Blankenburgs' construction of schools and the beginning of the study process in them. The Ministry of Education also regularly reported on the progress of construction and current events at schools. It is logical that these reports featured also the name of the school designer I. Blankenburgs [22]. For example, in 1933, in the popular magazine "Atpūta» («Rest») attention was paid to the construction of schools in Latvia since 1927. The most photographed were the school buildings designed by I. Blankenburgs [23]. An informative article with a wide description of school buildings designed by $I$. Blankenburgs in 1935 can be found in the newspaper «Pēdejjā Brīdī» («In the last moment») [24].

Figure 4. Indrikis Blankenburgs in the early 1930s [25].

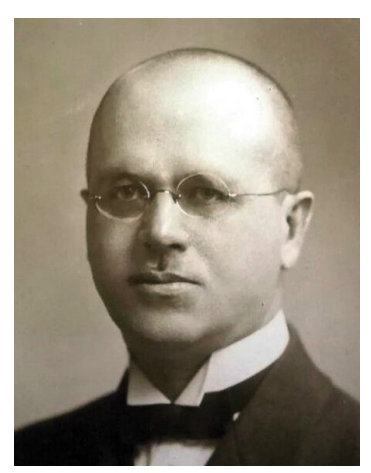

The family of Indrikis Blankenburgs (1887-1944) and Architectural Projects in the Turn of the Century 
Information about the work of Indrikis Blankenburgs for the first time in the press, was widespread in connection with plans for the construction of the Jaunburtnieki Parish School in 1923. The architect was promptly developing a project [26]. However, the new school in the parish was built only in 1936, to the project of I. Blankenburgs' student, graduate of the Department of Architecture (1913) of RPI - architect Pauls Kundzinš (1888-1983).

Indrikis Blankenburgs is known in the history of architecture in Latvia as a school architect. As can be seen in the list of buildings complied by the author, almost all of the school buildings designed by I. Blakenburgs still serve education. The projects of the educational institutions include functionalism, art deco and neoclassical style, which gave the monumental buildings a representative look. Schools designed by the architect (in Cèsis, Gulbene, Ilūkste, Ludza, Rucava, Rüjiena, Tukums, Valka, and Zilupe) and bank buildings are created in symmetrical, strictly classic forms with order elements in facade decoration. The school buildings in Dobele, Melluži and Smiltene, have more expressed functionalism [27]. In addition, the school buildings have an architecturally accentuated central part, on the upper floor of which there is a hall with larger windows (in Dobele, Ilūkste, Melluži, Rucava, Smiltene, Zilupe, etc.) [28]. The buildings by $I$. Blankenburgs have become symbols of recognisability of parishes and cities in Latvia. But the building of the present Aglona Catholic Gymnasium has been called «one of the most impressive secondary school buildings in Latvia ${ }^{3} »[29]$. The facades of architectural projects developed by architect Blankenburgs are made in classical proportions, with an emphasis on the middle section. The architect designed schools according to the requirements of that time. For example, at that time the Riga Second State Gymnasium at Ägenskalna Street in 1931 was built as the most modern school in Riga, the capital city of Latvia. It differed from the other projects by I. Blankenburgs. It was from red bricks on a high, light-coloured plinth [30]. In contrast to the uncovered bricks, a pargetted base floor and eaves were formed [31]. The gymnasium was designed for 330 students with spacious, bright classes, wide corridors, rooms for classes in physics, natural sciences, and chemistry, drawing rooms, gymnastics hall, wide hall, showers and a dining room. It is interesting that almost simultaneously with the school building at Ägenskalna Street, the largest and also the international project - the design and construction of the Riga French Lyceum building - was developed. Total cost of this project was 400000 lats, half of which was covered by the Latvian Government, and another half by the Society of Latvian-French Proximity and grants from the French government [32].

3 At different times, the Aglona Gymnasium had different names. 


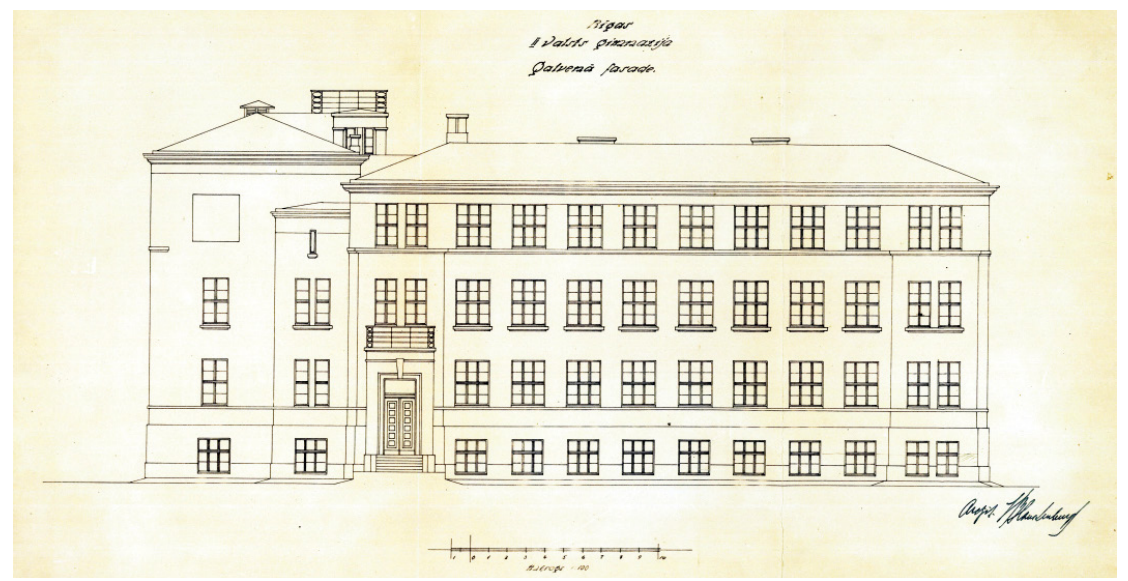

The family of Indrikis Blankenburgs (1887-1944) and Architectural Projects in the Turn of the Century

Figure 5. The main facade of the Riga Second State Gymnasium designed by I. Blankenburgs, a project with a signature, the end of the 1920s [33].

Figure 6. View of the main facade of the Riga Second State Gymnasium in the mid-1930s [34].

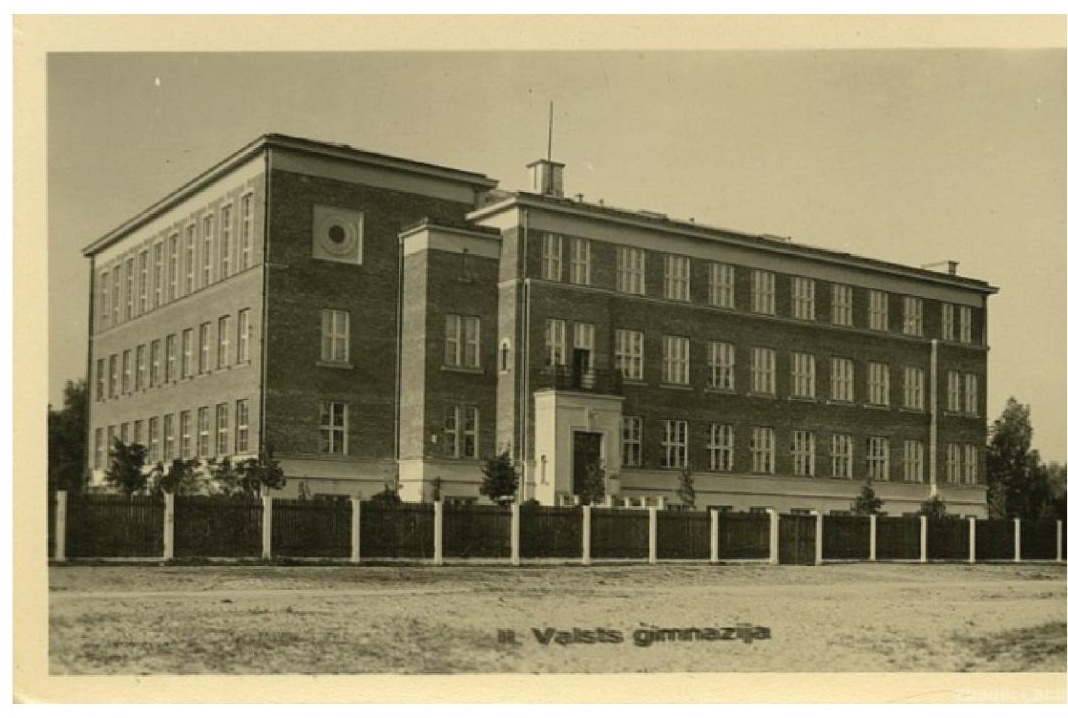

Often the developed school projects turned out to be expensive and were not realized, therefore other architects, including Indrikis Blankenburgs, whose projects were less costly, were chosen. It was easier to get his projects approved at different institutions. Members of the Jékabpils City Council got to know about that and rejected a project started by engineer Pétersons, they wanted I. Blankenburgs to draft a project for a primary school [35]. The Jékabpils City Council sent accountant Borodovskis and teacher Jékabs Drikis on a visit to Gulbene to see the Gulbene State Commercial and Vocational School designed by I. Blankenburgs, to make sure that the choice in favour of the architect was correct. 


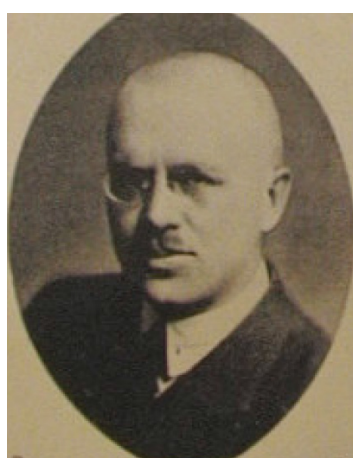

Figure 7. I. Blankenburgs in the second half of 1930s [36].

I. Blankenburgs did not always succeed in developing perfect building projects. Customers increasingly wanted cheaper and more comfortable buildings, but sometimes the construction supervisors also had their objections. For example, in 1929, I. Blankenburgs' project of the Riga French Lyceum on the corner of Valdemāra and Aristīda Briāna streets had some shortcomings - «different directions of opening of several doors, the wooden constructions were too close to the chimneys, uncomfortable entrance to the boiler house», which were eliminated by the designer during the construction of the building [37].

In some cases, the contribution of Latvian architects is also analysed in a critical light. For example, this approach was used by architect Jūlijs Lūsis (1894-1965) in the newspaper «Students» («Student») in 1935, when writing about the 1st Latvian Architectural exhibition at the Riga City Museum of Art. He criticized also architect I. Blankenburgs: «To a special third group belong the so-called ideologically «frozen», represented by I. Blankenburgs. His works have a weak classical rhyme, they are pale, lifeless, an seem dusted. Thanks to the opportunity to build a lot of buildings, I. Blankenburgs has created a real «crown style» of Latvian schools. If school architecture had the task of expressing the emptiness, boredom and indifference of spiritual stress, the facades of Blankenburgs' schools would have done their job really brilliantly [38].»

After evaluating the work of I. Blankenburgs from the time-distance in the 21st century, it has to be concluded, that he was one of the most visible representatives of functionalist architects of Latvian schools. Several of his building projects are eligible for inclusion in the International Latvian Register DoCoMoMo (International Working Party for Documentation and Conservation of Buildings, Sites and Neighbourhoods of the Modern Movement) [39]. According to expert opinions and ratings, there was nothing surplus in this type of school buildings. They conformed to the principles of modernism and business, which were in harmony with the forms of Neo-classicism. 
Not all projects developed by I. Blankenburgs were implemented. For example, the implementation of the Daugavpils City 4th Elementary School was delayed due to the fact that the Daugavpils City Board wanted to reduce the estimated construction costs - 350000 lats, by 40000 / 50000 lats. Also, President Kärlis Ulmanis gave instructions on saving money for the construction of new buildings. It was decided that the construction project would be amended, thus reducing the cost of construction works. It was planned to complete the construction of the Daugavpils City 4th Elementary School in autumn 1941 [40]. It is known that in the fall of 1940, with the state powers changed, the Council of People Commissars of the Latvian Soviet Socialist Republic approved the project of the school, drafted by architect $A$. Borbala [41]. The primary school after the Blankenburgs' project was not realised also in Rauna village, where on 12 December 1938 the Council decided to build a new school after the fire at the Rauna Secondary Elementary School [42]. The political situation changed, and later the Second World War began, the citizens of Rauna lived without a new school until 1956.

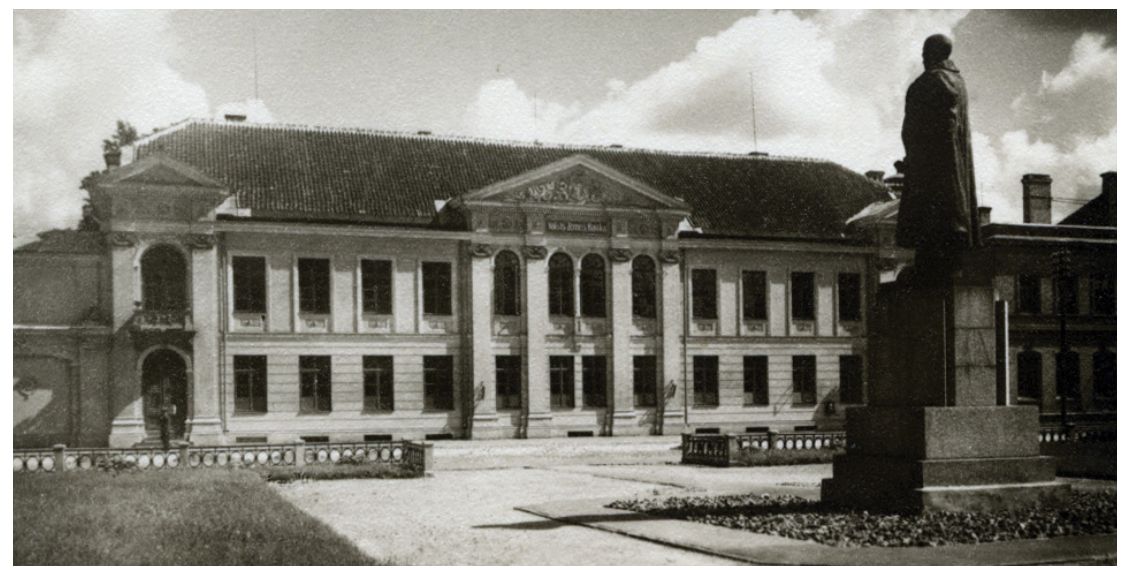

Figure 8. Building of the National Land Bank in Jelgava city, around 1930s [43].

I. Blankenburgs has also worked on the projects of bank buildings in Alūksne, Jelgava and Kuldiga cities, has developed a project for the annex of the Latvian State Historical Archive at Slokas Street in Riga, the Christ the King Church at 86 Meža prospekts, Sarkandaugava (together with Kārlis Reisons) [44], designed living houses in Riga, Madona, etc. cities. After his project in 1924-1925, Pāles Agricultural Society House [45] was rebuilt.

Indrikis Blankenburgs was one of the founders and leaders of the Latvia Society of Architects (1924) (former - Latvia Association of Architects). 
In 1934, he was awarded the Order of Three Stars for his achievements in architecture.

List of school buildings in Latvia designed by I. Blankenburgs (research results as of 05.05.2018)

\section{Designed buildings, year of construction, address}

1. Dzelzava Elementary School (in cooperation with architect $P$. Kundziņš), 1921, Dzelzava parish

2. L Laudona Agriculture School, 1923 (in cooperation with architect J. Orleāns), L,audona parish

3. Krustpils State Elementary School, 1924, 192 Rìgas Street, Jēkabpils city

4. Ilūkste State Elementary School, 1925-1927, 49 Raina Street, Ilūkste city

5. Zilupe State Elementary, 1925, 1 Skolas Street, Zilupe city

6. Gulbene State Commercial and Vocational School, 1927, 10 Skolas Street, Gulbene city

7. Ludza State Secondary School, 1927, 4 Blaumana Street, Ludza city

8. Tukums Secondary School, 1927-1936, 3 Raing Street, Tukums city

9. Rēzekne State Commercial School, 1928, 71 Atbrīvošanas Avenue, Rēzekne city

10. Rēzekne State Secondary School and Teachers Institute, 115 Atbrīvošanas Avenue, Rèzekne city

11. Jelgava School for deaf and hearing impaired children, 1928, 50 Filozofu Street 50, Jelgava city

12. Istra Elementary School, 1928, Vecslabada, Istra parish

13. Aglona Gymnasium, 1928-1939, 5 A. Broka Street, Aglona parish

14. Lìvāni Elementary School, 1929, 3 Domes Street, Lìvāni city

15. Vilaka State Gymnasium, 1929-1931, 11 Pils Street, Vilaka city

16. Valmiera State Deaf School, 1929, 5/7 L. Paegles Street, Valmiera city

\section{Building status as of 1 January 2018}

Dzelzava Elementary School

Burned, the building is not used

Jēkabpils Elementary School

Ilūkste Parish 1st Secondary School

Zilupe Secondary School

Gulbene Gymnasium

Ludza State Gymnasium

Tukums Ernests Birznieks-Upītis 1st Elementary School

The building was destroyed during an air raid in 1944 and has not been restored

Rēzekne Higher Education Institution

Jelgava 2nd Boarding Elementary School

Istra Secondary School

Aglona Catholic Gymnasium

Livani Engineering and Innovation Centre

Vilaka State Gymnasium

2nd Basic Boarding School for Hearing Impaired Children in Valmiera Development Centre 
17. Balvi State Gymnasium, 1930, 3 Dārza Street, Balvi city

18. French Lyceum, 1930, 48 Valdemāra Street, Rīga city

19. Nīca Elementary School, 1930, 14 Skolas Street 14, Nīca municipality

20. Indra Secondary School, 1930, 1 Skolas Street, Indra village

21. Rūjiena State Gymnasium, 1931, 24 Skolas Street, Rūjiena city

22. Valka State Gymnasium, 1931, 28a Raina Street, Valka city

23. Riga Second State Gymnasium, 1931, 21 Āgenskalna Street 21, Rïga city

24. Jūrmala City 3rd Elementary School, 1932-1938, 8 Kronvalda Street, Jūrmala city

25. Dubulti Secondary School (Kūrmāja reconstruction), 1933, Jūrmala city

26. Ance Elementary School kola, 1933, Ance parish

27. Trapene State Elementary School, 1934-1936, Trapene parish

28. Rucava State Elementary School, 1934-1938, Rucava municipality

29. Restoring of Jelgava Real School for Jelgava Teacher Institute needs, 1935, 18 Svētes Street 18, Jelgava city

30. Riga State Technical School, annex to the main building (to Noliktavas Street), 1935 [46], Rìga city

31. Smiltene State Gymnasium, 1936, 27 Dakteru Street, Smiltene city

32. Zemgale State Elementary School, 1936-1937, Demene parish

33. Medumi State Six-Class Elementary School, 1936-1937, 18 Alejas Street, Medumi parish

34. Saliena State Elementary School, 1936-1937, 23 Centrāles Street, Saliena village

35. Dobele Elementary School, 1938, 2 Dzirnavu street, Dobele city

36. Aknīste State Six-Clas Elementary School, 1937-1938, 19 Skolas Street, Akniste city

37. Friendly Appeal Cēsis State Gymnasium, 1937-1938, 1 L. Paegles Street, Cēsis city

38. Skrudaliena State Elementary School, 19371938, 12 Miera Street, Skrudaliena parish
Balvi State Gymnasium

Renovation of the Riga French Lyceum

Nīca Secondary School

Indra Elementary School

Rūjiena Secondary School

Jānis Cimze Valka State Gymnasium

Riga State German Grammar School

Pumpuri Secondary School

Demolished in 1970

Ance Elementary School

Trapene Elementary School

Rucava Elementary School

Faculty of Economics and Social

Development of Latvia University of Agriculture

Riga State Technical practical training Centre «Riga State Technical School»

Smiltene Secondary School

Zemgale Secondary School

Medumi Elementary School

Saliena Secondary School

Dobele State Gymnasium

Aknīste Secondary School

Cēsis State Gymnasium

Skrudaliena Elementary School (till 2016/2017 study year); multifunctional centre
The family of Indrikis Blankenburgs (1887-1944) and Architectural Projects in the Turn of the Century 
39. Pededze Elementary School, 1938, «Rūki», Pededze village

40. Rìga 3rd State Gymnasium (former Lomonosov Gymnasium), 1938, 29 Raina Boulevard, Rìga city

41. Dāvis Ozolinšs State Elementary School, 1939, 26 Pasta Street, Ape city

42. Varnoviči State Elementary School, 1939, Kaplava parish

43. Mazirbe Elementary School, 1940, «Mazirbes skola», Mazirbe village
Pededze Elementary School

Institute of Mathematics and Computer Science of Agency of University of Latvia

Dāvis Ozoliņ̌s Ape Secondary School

Varnavičs Library of Kaplava Parish

Mazirbe Boarding Elementary School

\section{LIST OF SOURCES AND LITERATURE}

[1] Latvijas Valsts vēstures arhīvs (turpmāk - LVVA) 2996. f., 2. apr., 30113. l.

[2] LVVA 2942. f., 1. apr., 11082. 1., 16. lp.

[3] LVVA 2996. f., 2. apr., 30108.lp.

[4] Aizvestie: 1941. gada 14. jūnijs. Rīga: Latvijas Valsts arhīvs, Nordik, 2007, 449. lpp.

[5] [3. personu saraksts]. Valdības Vēstnesis, 1939, No. 253, 11.-12. Ipp.

[6] LVVA 2942. f., 1. apr., 11082. 1., 65. lp.

[7] Indrikis Teodors Blankenburgs. Talavija, 1900-1925. Rīga: Valters un Rapa, 1928, 98. lpp.

[8] LVVA 7175. f., 1. apr., 1907. l., 213.lp.

[9] Indriḳis Blankenburgs - studentu korporācijas «Talavija» krāsnesis 20. gadsimta sākumā . RVVG̣ muzeja krājums.

[10] Valdības iestāžu paziņojumi. Valdības Vēstnesis, 1924, No. 162, 1. lpp.

[11] Pārmaiṇas Izglītības ministrijai padoto darbinieku sastāvā. Skolu departaments. Izglïtības Ministrijas Mēnešraksts, 1938, No. 4, 532. lpp.

[12] Talavija, 1900-1925. Rīga: Valters un Rapa, 1928, 98. lpp.

[13] Raisters, A. Architekta I. Blankenburga pieminai. Architekts, 1965, No. 13, 27.-28. Ipp.

[14] LVVA 2996. f., 2. apr., 30104. 1., 3.-5. lp.

[15] Meklē piederīgos. Dzimtene, 1945, No. 1, 2. lpp.

[16] Nekrologs. Laiks, 1990, No. 67, 7. lpp.

[17] I. Blankenburga un K. Kurle-Kurḷa kaps un piemineklis pēc restaurācijas 2. Meža kapos 2014. gada rudenī. RVVG̣ muzeja krājums.

[18] Raisters, A. Architekta I. Blankenburga pieminnai. Architekts, 1965, No. 13, 27. lpp.

[19] Mums zudušie kollēgas. Architekts, 1950, No. 1., 13. lpp.

[20] Zvaigzne, M. Rīgas Valsts vācu gimnāzija laikmetu griežos. Palīgs muzeja pedagogam (sast. Z. Soboḷeva). Rīga: RaKa, 2015, 98. lpp. 
[21] Arhitekta I. Blankenburga projektēto skolu èku saraksts un kontaktinformācija. Pieejams: https:www.skolumuzejubiedriba.lv/arhitekta_i_blankenburga_projekteto_skolu_eku_saraksts_un_kontaktinformacija [skatīts: 30.12.2017]

Blankenburgs (1887-1944) and Architectural

[22] Izglītības ministrija valsts pastāvēšanas trešajā piecgadē. Izglītības MinisProjects in the Turn of the Century

[23] Latvijas gaismas pilis. Atpūta, 1933, No. 461, 16.-17. lpp.

[24] Visos novados paceḷas skaistas gaismas pilis. Pēdējā Brīdī, 1935, No. 59, 10.lpp.

[25] LVVA 3234. f., 33. apr., 54226. 1., 3. lp.

[26] Jaunburtnieku pagasta skolas nams. Latvijas Vēstnesis, 1923, No. 62, 5. lpp.

[27] Krastinšs, J. Rīgas arhitektūras meistari, 1850-1940. Rīga: Jumava, 2002, 286. lpp.

[28] Krastiņš, J., Strautmanis, I., Dripe, J. Latvijas arhitektūra no senatnes līdz mūsdienām. Rīga: Baltika, 1998, 169. lpp.

[29] Rancāns, F. Aglona. Universitas, 1993, No. 70, 9. lpp.

[30] Caune, K., Vītola, G. Indrikisis Blankenburgs - skolu arhitekts. Zinātniskās pētniecības darbs (ap 2014). RVVG̣ muzeja krājums.

[31] Ārends, P. Rīgas modernās sabiedriskās celtnes. Senatne un Māksla, 1936, No. 3, 162. lpp.

[32] Apskats, Izglītības Ministrijas Mēnešraksts, 1930, No. 10, 363.-369. lpp.

[33] I. Blankenburga projektētās Rīgas II Valsts gimnāzijas galvenā fasāde, projekts ar parakstu, 20. gadsimta 20. gadu beigas. RVVG̣ muzeja krājums.

[34] Skats uz gimnāzijas galveno fasādi 20. gadsimta 30. gadu vidū. RVVG̣ muzeja krājums.

[35] Jēkabpils pilsētas domes sēde. Jēkabpils Vēstnesis, 1930, No. 19, 2. lpp.

[36] I. Blankenburgs 30. gadu 2. pusē. RVVG̣ muzeja krājums.

[37] Apsītis, V. [Atmiṇu zīmējumi]. Franču Licejs, 1921-1940. Rakstu krājums (sast. J. Leimanis). Rīga: Franču licejs, Absolventu biedrības valdes izdevums, 1991, 104. lpp.

[38] Lūsis, J. Architektūras izstāde. Students, 1935, No. 218, 5.lpp.

[39] Zībārte, I. Vairāk cieṇas, mazāk baiḷu. Dienas pielik. Sestdiena, 2002, No. 293, 18.-23. lpp.

[40] Daugavpils pilsētas 4. pamatskolu cels pēc Prezidenta norādījumiem. Daugavas Vēstnesis, 1939, No. 30, 2.lpp.

[41] Tautas komisaru padomes lēmumi. Brīvais Zemnieks, 1940, No. 52, 2. lpp.

[42] Raunā pacelsies stalta skolas ēka. Smiltenes Zingas, 1938, No. 50, 2. lpp.

[43] Valsts zemes bankas ēka Jelgavā, 20. gs. 30. gadi. G̣. Eliasa Jelgavas Vēstures un mākslas muzeja krājums.

[44] LVVA 6343. f., 20. apr., 77. 1., 35.-38. lp.

[45] Slaucītājs, K. Sabiedriskā dzīve Vidzemes jūrmalas apgabalā. Ārpusskolas Izglìtïba, 1929, No. 12, 327. lpp.

[46] Vitckopfs, Ā. Rīgas Valsts technikums Latvijas brīvvalsts gados. Technikas Apskats, 1965, No. 48, 11.lpp. 


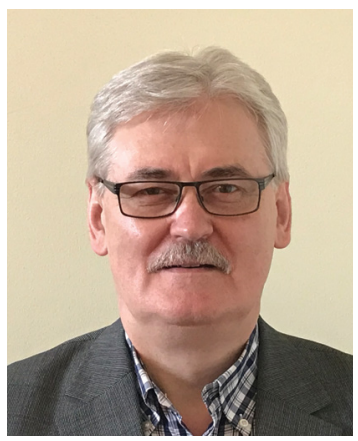

MĀRIS ZVAIGZNE, Mg. hist., is currently a history teacher at the Riga State German Grammar School and at the Engineering High School of Riga Technical University. He completed his doctoral studies at the Faculty of History and Philosophy of the University of Latvia in 2014. His main research interests and activities are the history of Soviet Trade Unions in Latvia (1940-1990) and history of Latvian schools. He is a member of the Association of School Museums of Latvia. He has published articles in academic journals and in the Latvian press.

Adress: 21 Āgenskalna Street, Riga, LV-1048, Latvia

Phone: 37126005464

E-mail: maris_zvaigzne@inbox.lv

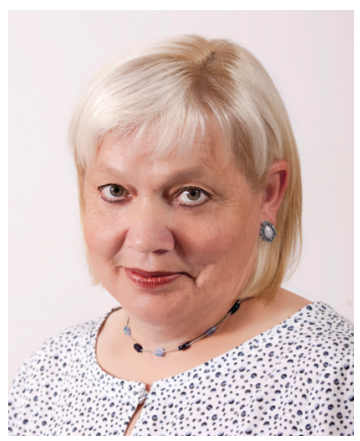

ALİDA ZIGMUNDE, Dr. paed., has been a Specialist at the Museum of Riga Technical University since 1989. From 2007 to 2015, she was a Senior Researcher. She is currently a Professor at the Institute for Humanities and Head of the Department for Historic Research and Scientific Publications of the RTU Research Centre for Engineering History. Her main academic interests include the history of pedagogy in Europe, the history of the institutions of education and of private schools, and the history of pedagogy of universities, history of engineering sciences and universities.

Address: 1 Kronvalda Boulevard, Riga, LV-1010, Latvia

Phone: +37129869642

E-mail: alida.zigmunde@rtu.lv

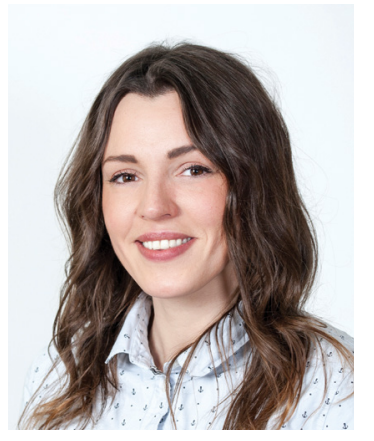

Address: 1 Kronvalda Boulevard, Riga, LV-1010, Latvia

Phone: +371 28897223

E-mail: ilze.gudro@rtu.lv
ILZE GUDRO, Dr. sc. ing., is currently Head of the Research Centre for Engineering History of Riga Technical University and a lecturer with the Institute of Design Technologies of RTU. Her main academic interests include the history of Riga Technical University, engineering sciences, interior, furniture and product design, materials science. She is a member of the team organizing the exhibitions of works of bachelor and master students of the Institute of Design Technologies of RTU (e. g. Fashion show «Kipsalas Pavasaris», design product exhibitions «Kīpsalas Dizaina Kods», «Design Isle» etc.). 


\section{Arhitekta Indriḳa Blankenburga (1887-1944) dzimta un projekti} laikmetu griežos

Blankenburgs (1887-1944) and

Architectural

Arhitekts Indriḳis Blankenburgs (1887-1944), Rīgas Politehniskā institūta (RPI) Arhitektūras nodaḷas absolvents (1913), ir viens no pazīstamākajiem Projects in the Turn of the Century skolu ēku projektētajiem Latvijā starpkaru laikā. Vairums no viṇa vairāk nekā 30 projektēto skolu un citu celtṇu joprojām tiek izmantotas arhitekta sākotnēji paredzētajiem mērksiem. Izmantojot Latvijas Valsts vēstures arhīva dokumentus un bibliotēku krājumus, rakstā izsekots Blankenburgu dzimtai, kā arī ieskicēts I. Blankenburga devums skolu arhitektūrā, sastādīts arhitekta projektēto skolu saraksts.

Atslēgas vārdi: Indriḳis Blankenburgs, Blankenburgu dzimta, skolu projekti.

\section{Марис Звайгзне, Алида Зигмунде, Илзе Гудро}

\section{Род архитектора Индрикиса Бланкенбурга (1887-1944) и его проекты в течении эпох}

Выпускник Архитектурного отделения Рижского политехнического института (1913) Индрикис Бланкенбург (1887-1944) является одним из самых известных проектировщиков школьных зданий межвоенного периода Латвии. Из его более чем 30 спроектированных школ и других строений большинство зданий продолжают по-прежнему использоваться для первоначально задуманной архитектором цели. Используя документы Государственного исторического архива Латвии и фонды библиотек, исследован род Бланкенбургов, проаналицирован вклад И. Бланкенбурга в архитектуру учебных заведений, составлен перечень спроектированных архитектором школ.

Ключевые слова: Индрикис Бланкенбург, семья Бланкенбургов, проекты учебных зданий. 